Vernacular Voices 


\section{JEWISH CULTURE AND CONTEXTS}

Published in association with the Herbert D. Katz Center for Advanced Judaic Studies of the University of Pennsylvania

David B. Ruderman, Series Editor

Advisory Board

Richard I. Cohen

Moshe Idel

Alan Mintz

Deborah Dash Moore

Ada Rapoport-Albert

Michael D. Swartz

A complete list of books in the series is available from the publisher. 


\title{
Vernacular Voices
}

Language and Identity in

Medieval French Jewish Communities

\author{
Kirsten A. Fudeman
}

\section{PENN}

UNIVERSITY OF PENNSYLVANIA PRESS

PHILADELPHIA • OXFORD 
Copyright (C) 20I0 University of Pennsylvania Press

All rights reserved. Except for brief quotations used for purposes of review or scholarly citation, none of this book may be reproduced in any form by any means without written permission from the publisher.

Published by

University of Pennsylvania Press

Philadelphia, Pennsylvania I9IO4-4II2

Printed in the United States of America on acid-free paper

$\begin{array}{llllllllll}\text { IO } & 9 & 8 & 7 & 6 & 5 & 4 & 3 & 2 & \text { I }\end{array}$

Library of Congress Cataloging-in-Publication Data

Fudeman, Kirsten Anne.

Vernacular voices : language and identity in medieval French Jewish communities / Kirsten A. Fudeman.

p. cm. - (Jewish culture and contexts)

Includes bibliographical references and index.

ISBN 978-0-8I22-4250-8 (hardcover : alk. paper)

I. Hebrew language, Medieval-France. 2. Jews-

France-Languages-History. 3. Jews-France-Identity.

4. Jews-France-History-To I500. I. Title.

PJ4995.F8F83 2010

492.4' 7-dc22 
For Alexander and Gregory 
